\title{
Der Milbenjäger
}

Erhard Taverna

* Spezialist für mobile Matratzentiefenreinigung Heinz Greuter, Oetlisbergstrasse 38a, 8035 Zürich, Telefon 0443816036 .
Trotz aller Forschungsprojekte bleibt vieles unklar; fest steht nur, dass Allergien zunehmen. Jedes vierte Kind unter zehn Jahren leidet unter Asthma, Rhino-Konjunktivitis oder atopischen Ekzemen. Trotz ähnlichem Lebensstil zeigt der Ländervergleich einer europäischen Studie grosse Unterschiede: 32,2\% in England gegen $3,7 \%$ in Griechenland, 16\% in Finnland und Malta und mehr Fälle im Osten als im Westen. Wer morgens regelmässig mit den genannten Symptomen aufwacht und weder erkältet ist noch an Heuschnupfen leidet, reagiert mit hoher Wahrscheinlichkeit auf den allergenhaltigen Milbenkot im Hausstaub.

Nachdem er seinen schweren Samsonitekoffer vier Stockwerke hochgeschleppt hat, beginnt Heinz Greuter* seinen Spezialstaubsauger zusammenzuschrauben. Als freier Unternehmer erreichen ihn die meisten seiner Kunden über die Empfehlung von Matratzenherstellern oder auf Anraten von Hausärzten und Spezialisten wie Dermatologen und Pädiater. An den Bürstenkopf mit der rosshaargespickten Vibrationswalze wird das Saugrohr gesteckt und der Motor mit Gebläse auf den mit Leitungswasser halbgefüllten Tank montiert. Dann rollt der das Gerät an den Tatort, in der Regel ein Schlafzimmer mit Matratze. Sorgfältig wird jeder Quadratzentimeter wiederholt abgesaugt, die Matratze gewendet und erneut traktiert. Die im Filtertank rotierende Flüssigkeit verfärbt sich braun, und ein dicker Schaumteppich beginnt über der dunklen Brühe zu rotieren.

Unser liebster Gegenstand, auf dem wir etwa einen Drittel unseres Lebens verbringen, ist ein wunderbares Naturreservat. Denn im Mikroklima teurer Naturprodukte und billigster synthetischer Fabrikate gleichermassen, finden wärmeliebende Schimmelpilze und symbiotisch lebende Milben ihr Schlaraffenland. Bei 25 Grad Wärme und 70- bis 80-prozentiger Luftfeuchtigkeit gedeihen sie am besten. Die Pilze scheiden Enzyme aus, die die für Milben giftigen Fettanteile unserer Schuppen vorverdauen, und die Milben verbreiten die Sporen über ihren Verdauungstrakt. Im Bett geht es den achtbeinigen Spinnentierchen am besten Die Menschen liefern feuchte Säfte und Wärme, Nahrung und Schmutz.

Natürlich saugt Heinz Greuter die unsichtbaren Gäste auch aus Liegefellen, Teppichen und Vorhängen, doch da sind sie weit spärlicher vorhanden und natürlichen Feinden wie Raubmilben, Silberfischchen und Staubläusen ausgesetzt. Er macht gerne Hausbesuche, das ist praktischer, als eine Matratze ausser Haus zu transportieren. Acht weitere Kollegen seien im ganzen Land auf Milbenjagd. Zum Revier gehören auch Ferienhäuser und Pflegeheime, weniger Spitäler, für deren Betten andere Hygieneregeln gelten.

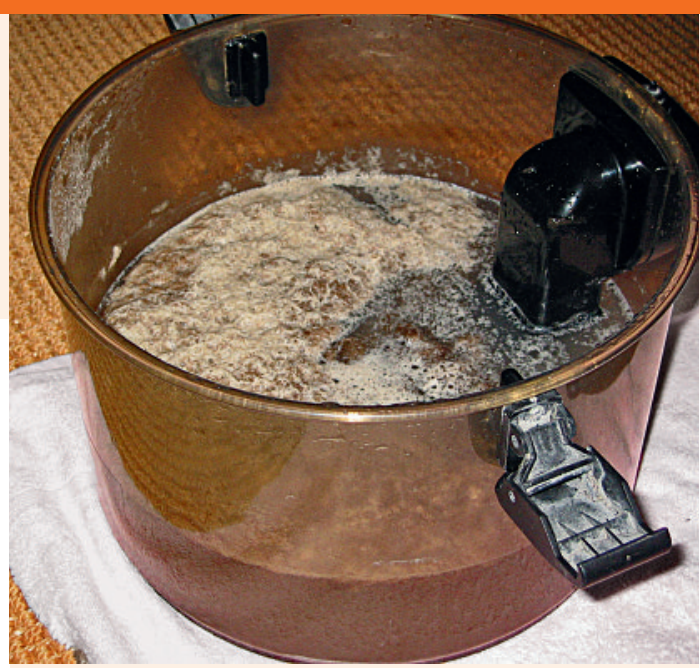

Oben Milbenteile, Fettreste und Proteine, in der Mitte Staubpartikel und Salzteile, und darunter Schlamm aus sedimentierten Schmutzteilen und Textilfasern.

Versiegelte Innenräume und Zentralheizungen haben das Wohnen verändert. Er erinnert sich noch an die Teppichstangen mit den ausklappbaren Gitterrosten, die zum Inventar der teppichklopfenden 50er Jahre gehörten. Ob unser Immunsystem damals mehr oder weniger gefordert war, ist in der Fachwelt eine offene Frage. Wo eine Sanierung unumgänglich wird, bieten sich viele Methoden an. Es gibt milbendichte Überzüge (Encasing), zerlegbare Matratzen, die sich waschen lassen, eingearbeitete Bitterstoffe, Sprays und neuerdings auch heizbare Produkte, die das unerwünschte Biotop thermisch vernichten. Von Luftbefeuchtern sei in jedem Fall abzuraten, überflüssige Staubfänger zu entfernen, der gute alte Molton sehr empfehlenswert, und einmal wöchentlich Staubsaugen genüge.

So spricht der Fachmann und offenbart dem staunenden Laien den Inhalt des nun dreischichtigen Wassertankinhaltes. Oben schwimmt die schaumgeschlagene Eiweissschicht aus Milbenteilen, Fettresten und Proteinen, dem folgt die hellere Schicht mit Staubpartikeln und Salzteilen über dem fast schwarzen Schlammgrund der sedimentierten Schmutzteile und Textilfasern. Die Brühe landet in der Toilette. Der Meister reinigt sorgfältig das zerlegte Instrument und verstaut es wieder in seinem roten Koffer. Einem Tee ist er nach getaner Arbeit nicht abgeneigt.

Viele Kunden wünschten noch ein Beratungsgespräch, das er aus seinem dicken Ordner mit furchteinflössenden Milbenvergrösserungen, Statistiken und Merkblättern ergänzt. Im übrigen seien auch Futons nicht vor Befall gefeit und Wasserbetten geradezu ideale Biotope. Da müsste einer schon auf einer Holzpritsche oder einem Nagelbrett schlafen, was aber seinem Berufe nicht zugute käme. Gesundheit und Hygiene seien seine Steckenpferde, und ohne seine Pflege sei es doch schade um alle teuren Traumliegen. Dann kassiert er zu einem fairen Preis und schleppt seine Last die Treppen hinunter. Bis zum nächsten Mal, in einem Jahr. 